\title{
DISTRIBUTION OF IRON AND IRON COMPOUNDS IN THE KEMERI - JAUNKEMERI OCCURENCE OF SULPHIDE WATER
}

\author{
Janis Prols ${ }^{1}$, Ėrika Teirumnieka ${ }^{2}$, Edmunds Teirumnieks $^{2}$ \\ ${ }^{1}$ Geo Consultants Ltd, \\ Address: Olivu iela 9, LV-1004, Riga, Latvia, Telephone: +371 67627504; \\ fax:+37167623512; E-mail: janis.prols@geoconsultants.lv \\ ${ }^{2}$ Rezekne Higher Education Institution,
} Atbrīvošanas aleja 115, LV-4601, Rēzekne, Latvia, Tel. +371 4625150, Fax +371 4625901

\begin{abstract}
Iron concentrations, distribution and migration forms, depending on $\mathrm{pH}$ and oxidation - reduction potential, were analyzed in case of the Kemeri-Jaunkemeri occurrence (area about $240 \mathbf{~ k m}^{2}$ ) of sulphide containing water (maximal sulphides concentration - $74 \mathrm{mg} / \mathrm{l}$ ), located in Latvia. Iron content was investigated in 457 wells located within all area of occurrence. Those wells were installed to two aquifers: the Quarternary multi-aquifer and Salaspils aquifer, where occurrence of sulphide containing groundwater is distributed. All groundwater of occurrence is classified in four types depending on oxygen, sulphides and organic matter content in the groundwater. Modeling of groundwater migration forms was carried out, and it is stated that iron migrates basically as $\mathrm{Fe}^{2+}$ in oxygen and suphides non-containing water. Migration forms are influenced by concentration of organic matter in the aquifer. The portion of $\mathrm{Fe}^{2+}$ migrating in a form of free decreases due to formation of complexes with fulvic and humic acids, which can reach $36.5 \%$ of all migration forms. Iron migrates as $\mathrm{Fe}(\mathrm{OH})_{3}$ in oxygen containing water (more than $99 \%$ of determined forms). Presence of iron is ascertained also in sulphides containing water, where iron migrates basically as $\left(\mathbf{9 8 . 8 \%}\right.$ of determined forms). This occurs due to formation of complexes with sulphydes $-\mathrm{FeHS}^{-}$and $\mathrm{Fe}(\mathrm{HS})_{2}{ }^{\circ}$.
\end{abstract}

Keywords: groundwater exploration, hydrochemistry, iron, sulphides, Latvia.

\section{INTRODUCTION}

Iron in groundwater is one of elements which significantly influences groundwater quality, and distribution of iron forms in groundwater are depending on oxidation - reduction potential (Eh) and acidity/basicity $(\mathrm{pH})$ of water media [1]. Simultaneously geochemistry of iron in groundwater is rather complicated, because iron can migrate in groundwater not only as divalent ferrous iron $\left(\mathrm{Fe}^{2+}\right)$, trivalent ferric iron $\left(\mathrm{Fe}^{3+}\right.$ and their hydroxides, but also in a form of complexes with many inorganic and organic ligands. Iron state, concentrations and migration forms were investigated in the Kemeri Jaunkemeri occurrence of sulphides containing groundwater, because knowledge of iron geochemistry was important in order to understand genesis and distribution of sulphides in groundwater of the occurrence. The study area is located in Latvia, 40-60 $\mathrm{km}$ western form the capital of Latvia - Riga City (see Fig.1).

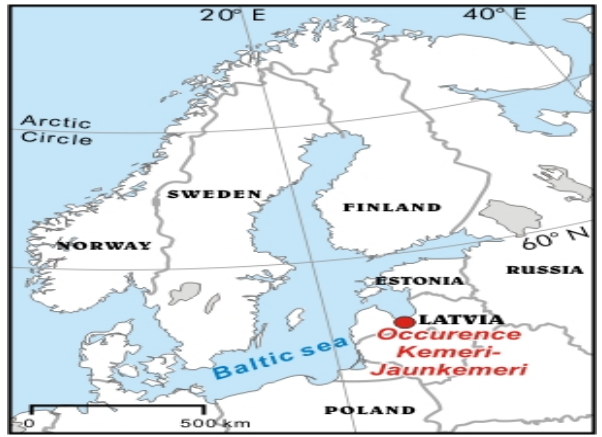

Fig. 1 Location pf the Study area

Area of the occurrence is about $240 \mathrm{~km}^{2}$, and it is distributed within the Salaspils aquifer of the Upper Devonian consisting of dolomite, gypsum, marl, clay deposits, in average $20 \mathrm{~m}$ thick. This aquifer is covered and here and there is in hydraulic link with the multi- aquifer of the Quaternary deposits [10]. 


\section{METHODS, THEIR SIGNIFICANCE AND SCOPE OF THE WORK}

Adequate sampling and conservation of groundwater samples and use of accurate analytical methods are required for acquisition of reliable data on iron concentration in water. Iron occurs in groundwater in dissolved and colloidal forms, and both of them include inorganic and organic forms of iron compounds. Therefore dissolved and colloidal forms of iron have to be separated before analysis if it takes place in situ. Conservation of sample must be provided, if it is delivered for analysis to the laboratory. Besides it has to be taken into account that difference in sizes of mentioned forms is rather relative. For example, size of iron hydroxides and sulphides is $<0.2 \mu \mathrm{m}$, but size of complex iron compounds with fulvic acids is $>1 \mu \mathrm{m}$. For that reason the membrane filter $0.45 \mu \mathrm{m}$ was used for filtration. Still, as it is stated in study [3], insignificant part of colloidal forms are passing filter. Nevertheless the difference observed for $0.45 \mu \mathrm{m}$ and for smaller size membrane filters, looking from analytical and hydrochemical viewpoints, is unessential for groundwater does not containing sulphides. Different is situation when groundwater contains sulphides, because very frequently colloidal forms of iron (for example, mackinawite - FeS) are found. Due to this reason membrane filter $0.2 \mu \mathrm{m}$ was applied. $\mathrm{pH}$ of groundwater distributed in the borders of occurrence is about neutral (excluding water from boggy deposits). In general water filtration is mandatory if $\mathrm{Fe}^{3+}$ is found, because in such conditions $\mathrm{Fe}^{3+}$ migrates only as colloid or complex compound with organic matter. Filtration is not necessary if water contains only $\mathrm{Fe}^{2+}$.

Samples were acidified with the $\mathrm{HCl}$ to $\mathrm{pH} \sim 1$, when they were delivered for analysis to the laboratory. It has to be emphasized that only total content of iron may be determined for acidified samples. In particular case it was important to determine directly $\mathrm{Fe}^{2+}$ and $\mathrm{Fe}^{3+}$ concentrations. Therefore major part samples, as rule, were analysed in situ. Hermetic sampling (excluding aeration) was provided in case of samples delivery to the stationary laboratory specially created at Kemeri in order to provide analysis within $0.5-1.5$ hours after sampling (time which was necessary for transportation). Photometric analysis was applied, where $\alpha, \alpha^{\prime}$ dipyridyl was used for iron determination. All complex compounds of iron where destroyed before analysis using $\mathrm{HNO}_{3}$ and $\mathrm{H}_{2} \mathrm{O}_{2}$ and heating samples whilst they were completely evaporated. Nonevaporated samples were analysed in parallel in order to determine part of iron complexes in total content of iron [6]. The thiocyanate method was applied only for rough analysis in single cases, where it was actually, in order iron content in field conditions, and obtained results are not used in this work.
Special programme "Echo" was elaborated for a modelling of migration forms of elements in groundwater taking into account principles described in the work [9], i.e. programme was based on unstableness constants of substances, taking into account $\mathrm{pH}$ and $\mathrm{Eh}$, chemical composition of water, gases content and organic matter concentrations as background information for a modelling purpose.

Iron content was investigated in 457 wells located within all area of investigations (see Fig.2). This was combined with $\mathrm{pH}$, Eh and $\mathrm{H}_{2} \mathrm{~S} \mathrm{HS}^{-}$determination in field conditions, as well as with groundwater sampling for determination of chemical composition $\left(\mathrm{Ca}^{2+}\right.$, $\left.\mathrm{Mg}^{2+}, \mathrm{Na}^{+}, \mathrm{Fe}^{2+}, \mathrm{Fe}^{3+}, \mathrm{HCO}_{3}{ }^{-}, \mathrm{SO}_{4}{ }^{2-}, \mathrm{Cl}^{-}, \mathrm{NO}_{3}{ }^{2-}\right)$, gasses content $\left(\mathrm{O}_{2}\right)$ and determination of organic matter $\left(\mathrm{C}_{\text {orgttot }}\right.$, fulvic acids and humic acids).

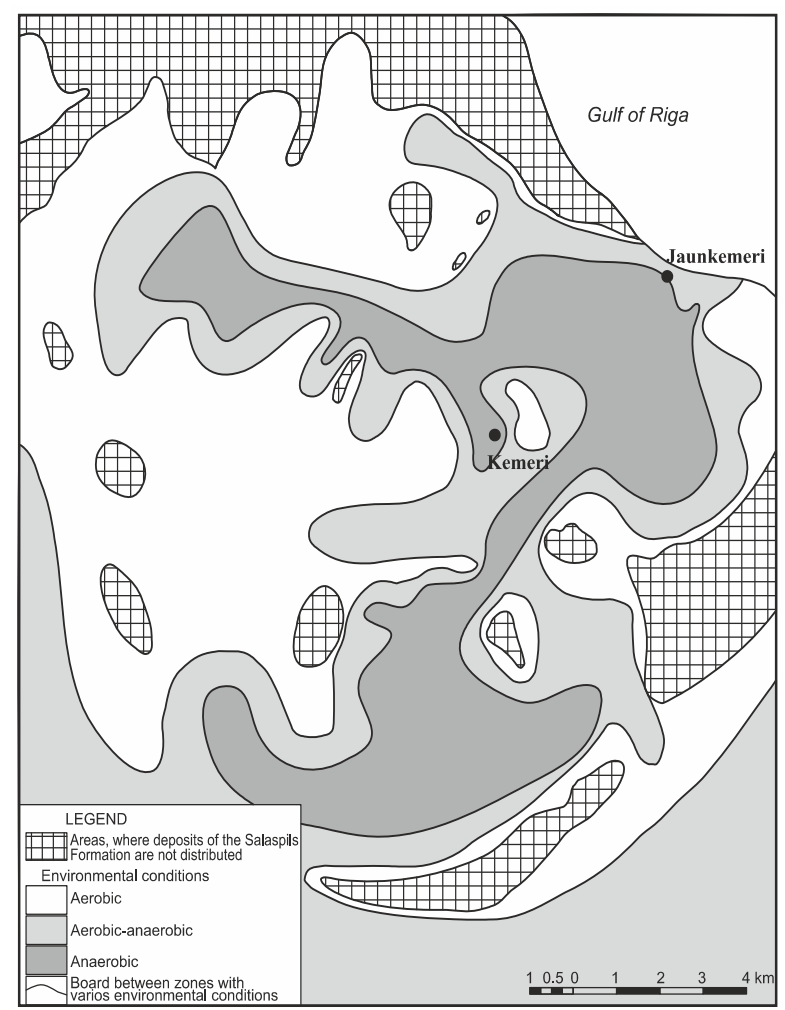

Fig. 2 Location of wells and zoning of oxidation - reduction conditions of the occurrence

\section{A. Theoretical aspects and classification of water of the occurrence}

Hypothetical plot showing a stability-field of different dissolved iron forms and compounds typical for groundwater, where $\mathrm{Eh}$ varies from $-400 \mathrm{mV}$ to $+500 \mathrm{mV}$, but $\mathrm{pH}$ from 4 to 10 , is presented in study [2] (see Fig. 3, part "a"). High clarke of iron (4.65 g/t) [9] determines existence of iron abundance gradient in the system "sediments-water". Consequently - any water containing sediments may be a source providing a presence of iron in groundwater. 


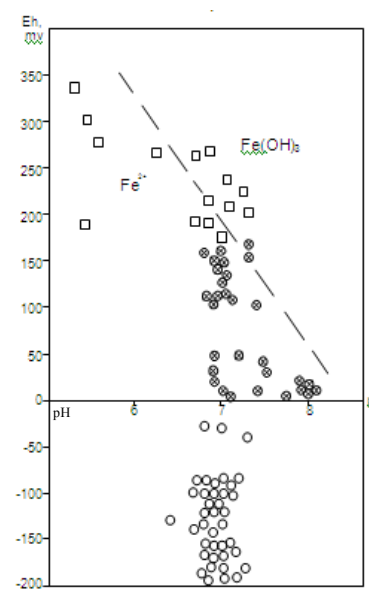

a)

berend

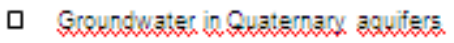

Q Groundwater in Salaspils aquifer.

- net centaining $\mathrm{O}_{2}$ and $\mathrm{H}_{2} \mathrm{~S}$

- Groundwater in Salaspils aquifer. sentaining $\mathrm{H}_{2} \mathrm{~S}$

Fig. 3. Dissolved iron in relation to $\mathrm{pH}$ and Eh: a) hypothetical plot [2]; b - plot for the Kemeri - Jaunķemeri occurrence of sulphides containing groundwater

Nevertheless, the direct link among iron content in sediments and in related groundwater is not stated [7]. Iron migration from sediments to water is possible only in particular oxidation - reduction conditions, in general are determined by the $\mathrm{pH}$ and Eh. Therefore iron distribution in groundwater, looking both from quantitative and qualitative aspects, is extremely different.

The iron forms in groundwater, taking into consideration that iron may be found as reduced divalent ferrous $\left(\mathrm{Fe}^{2+}\right)$ and oxidized trivalent ferric $\left(\mathrm{Fe}^{3+}\right)$, are determined by variety of factors. The most essential among them are five $[7,8]$ :

- poor $\mathrm{Fe}(\mathrm{OH})_{3}$ and good $\mathrm{Fe}(\mathrm{OH})_{3}$ solubility in water; their solubility constants are: $3.8 * 10^{-38}$ and $1 * 10^{-15}$,

- oxidation of $\mathrm{Fe}^{2+}$ in presence of $\mathrm{O}_{2}$ with further hydrolysis creating $\mathrm{Fe}(\mathrm{OH})_{3}$,

- formation of poorly soluble compounds in sulphides containing water $-\mathrm{FeS}$ and $\mathrm{FeS}_{2}$ having solubility constants $1 * 10^{-20}$ and $1 * 10^{-30}$,

- formation of poorly soluble compounds with anions distributed in groundwater,

- formation of complexes with ions and organic matter, especially with humic and fulvic acids.

All mentioned factors also have the particular role during the process of origin and existence of the Kemeri-Jaunkemeri occurrence of sulphides containing water. Very different types of water are distributed in the rather small area $\left(240 \mathrm{~km}^{2}\right)$ - starting from oxygen and ending with sulphides containing; moreover - groundwater has very different composition and content of dissolved substances.
Further only types of groundwater, characteristic for the Kemeri-Jaunkemeri occurrence of sulphides containing water, are examined (see Fig. 3, part "b"), and classified taking into consideration values of $\mathrm{pH}$, Eh, $\mathrm{O}_{2}$, sulphides $\left(\mathrm{H}_{2} \mathrm{~S}+\mathrm{HS}^{-}+\mathrm{S}^{2-}\right)$ and organic matter:

1) I type: oxygen (up to $4.2 \mathrm{mg} / \mathrm{l}$ ) containing and sulphides non-containing water with relatively low content of organic matter $\left(\mathrm{C}_{\text {org.tot }}<20 \mathrm{mg} / \mathrm{l}\right)$, where $\mathrm{pH}$ and $\mathrm{Eh}$ values varies from 6.5 to 7.5 and from +245 $\mathrm{mV}$ to $+390 \mathrm{mV}$ correspondingly. This type of water is dominantly distributed in the Quaternary multiaquifer, but also can be found in local areas in the Salaspils aquifer, where it is recharged, due to absence of glacial sediments, by water from the Quaternary multi-aquifer,

2) II type: oxygen and sulphides non-containing water, relatively poor with organic matter $\left(\mathrm{C}_{\text {org.tot }}<15\right.$ $\mathrm{mg} / \mathrm{l})$. This type of water is distributed in the Salaspils aquifer, where $\mathrm{pH}$ and Eh values varies from 6.8 to 7.5 and from $+10 \mathrm{mV}$ to $+160 \mathrm{mV}$ correspondingly. Link among Eh and $\mathrm{pH}$ has inverse character minimal and maximal Eh values observed in cases of maximal and minimal $\mathrm{pH}$, i.e. $\mathrm{Eh}=10 \mathrm{mV}$ if $\mathrm{pH}=7.4$ and $\mathrm{Eh}=160 \mathrm{mV}$ if $\mathrm{pH}=6.8$,

3) III type: oxygen and sulphides non-containing water, rich with organic matter $\left(\mathrm{C}_{\text {org.tot }}-\right.$ up to 90 $\mathrm{mg} / \mathrm{l}$ ), where $\mathrm{pH}$ is less than 6.5 and Eh varies from $+60 \mathrm{mV}$ to $+189 \mathrm{mV}$. This type of water is distributed in the Quaternary multi-aquifer, basically in aquifer of boggy sediments,

4) IV type: oxygen non-containing and sulphides containing water relatively poor with organic matter $\left(\mathrm{C}_{\text {org.tot }}<15 \mathrm{mg} / \mathrm{l}\right)$. Sulphides content reaches $74 \mathrm{mg} / \mathrm{l}$. $\mathrm{pH}$ and Eh values varies from 6.8 to 7.3 and from -10 $\mathrm{mV}$ to $-190 \mathrm{mV}$ correspondingly.

\section{B. Distribution of iron in oxygen containing groundwater}

Oxidation and hydrolysis take place in groundwater containing oxygen and relatively poor with organic matter, where $\mathrm{pH}$ value varies from 6.5 to 7.5 (I and II types of water). Following equations of reactions are describing those processes:

$\mathrm{Fe}^{2+} \rightarrow \mathrm{Fe}^{3+}+\mathrm{e}^{-}(1)$

$\mathrm{Fe}^{3+}+\mathrm{OH}^{-} \leftrightarrow \mathrm{FeOH}^{2+}+\mathrm{OH}^{-} \leftrightarrow \mathrm{Fe}(\mathrm{OH})_{2}^{+}+\mathrm{OH}^{-} \leftrightarrow$ $\mathrm{Fe}(\mathrm{OH})_{3}{ }^{0}+\mathrm{OH}^{-} \leftrightarrow \mathrm{Fe}(\mathrm{OH})_{4}^{-}{ }^{-}(2)$

The most stable compound, when $\mathrm{pH}$ is about neutral, is $\mathrm{Fe}(\mathrm{OH})_{3}$. Formation of colloids both in surface water and groundwater takes place, if solubility expression $\left(3,8 * 10^{-38}\right)$ of ferric iron is reached. G.Solomin has determined $\mathrm{Fe}^{2+}$ migration forms in oxygen containing groundwater already in 1967 [12], and has ascertained that those forms may be presented in following order:

$\mathrm{Fe}(\mathrm{OH})_{3}{ }^{\mathrm{O}}>>\mathrm{Fe}(\mathrm{OH})_{2}{ }^{+}>\mathrm{Fe}(\mathrm{OH})^{2+}>\mathrm{FeSO}_{4}{ }^{\circ}, \mathrm{FeCl}^{2+}$

where $\mathrm{Fe}(\mathrm{OH})_{3}{ }^{\mathrm{o}}$ absolutely dominates $(>99 \%$ of determined forms). $\mathrm{Fe}(\mathrm{OH})_{2}^{+}$and $\mathrm{Fe}(\mathrm{OH})^{2+}$ content is very low $\left(\mathrm{n}^{*} 0.1 \%\right)$, but $\mathrm{FeSO}_{4}{ }^{0}$ and $\mathrm{FeCl}^{2+}$ presence 
has rather theoretical character (less than $n^{*} 0.01 \%$ ). Similar conclusions provided also in other studies. For example, in study [2] it is mentioned that in presence of oxygen $\mathrm{Fe}(\mathrm{OH})_{3}{ }^{0}$ forms $99.0-99.9 \%$ of total iron forms.

When groundwater is saturated with $\mathrm{Fe}(\mathrm{OH})_{3}$, taking into account its low solubility, initially $\mathrm{Fe}(\mathrm{OH})_{3}$ is transformed to colloidal form with following precipitation forming brown colour sediments. Stability constant for the reaction $\mathrm{Fe}(\mathrm{OH})_{3}=\mathrm{FeOOH}+\mathrm{H}_{2} \mathrm{O}$ is $\sim 3,4 * 10^{6}$. It, taking into account stability constants of other forms, allows to determine the maximum free $\mathrm{Fe}^{3+}$ content which is in equilibrium with precipitation of $\mathrm{Fe}(\mathrm{OH})_{3}$. According [12] this concentration cannot be more than $17 \mathrm{mg}$ of $\mathrm{Fe}^{3+}$ per liter. This allows to make important conclusion - hydrolysis of $\mathrm{Fe}^{2+}$ and after of $\mathrm{Fe}^{3+}$ is taking place in groundwater containing oxygen. Consequently iron in groundwater of occurrence, where it contains oxygen, has to be completely precipitated.

This fact was proved during investigations, i.e. iron content in I type of water varies from 0.00 to 0.54 $\mathrm{mg} / \mathrm{l}$. It is important to emphasize that this conclusion has not only local, but also general character. According study [5], where iron distribution in groundwater in Lithuania was analysed, it is stated that maximum iron content does not exceed $0.38 \mathrm{mg} / \mathrm{l}$ if average concentration of $\mathrm{O}_{2}$ in groundwater is 0.38 $\mathrm{mg} / \mathrm{l}$.

C. Iron migration in groundwater non containing

$\mathrm{O}_{2}$ and $\mathrm{H}_{2} \mathrm{~S}$ poor with organic matter

Formation of oxygen and sulphides non containing water (II type) takes place in closed systems, where high concentrations of iron are possible only in case, when Eh of groundwater is lower that oxred potential of the reaction (1). This type of water is distributed in zone of occurrence of $\mathrm{Fe}^{2+}$ (see Fig. 3, part "b"), where iron content depends of solubility of the less soluble compound. For water, where $\mathrm{pH}$ is about neutral, these are carbonates. Following equation describes the solubility process in particular case [8]: $\mathrm{FeCO}_{3}+\mathrm{H}_{2} \mathrm{O}+\mathrm{CO}_{2}=\mathrm{Fe}^{2+}+2 \mathrm{HCO}_{3}(3)$

Analyzing the reaction, it has to be concluded that carbonate equilibrium shall be diverged towards $\mathrm{HCO}_{3}{ }^{-}$. Therefore iron concentration in water will not be determined by the weak soluble $\mathrm{FeCO}_{3}$ (solubility constant - $\left.2.3 * 10^{-11}\right)$, but by the high soluble $\mathrm{Fe}\left(\mathrm{HCO}_{3}\right)_{2}$ [4]. Presence of $\mathrm{CO}_{2}$ in groundwater is mandatory precondition for an increase of iron concentrations. In particular conditions source of $\mathrm{CO}_{2}$ are: oxidation of organic matter, biochemical processes and others.
Data on iron migration in water does not containing $\mathrm{O}_{2}$ and sulphides is presented in Table 1 both for the Quaternary multi-aquifer and for the Salaspils aquifer. $\mathrm{pH}$ and $\mathrm{Eh}$ of this type of water varies from 6.7 to 7.4 and from $+50 \mathrm{mV}$ to $+200 \mathrm{mV}$ correspondingly. It is ascertained that in the Quaternary multi-aquifer more than $83 \%$ of iron migrates as $\mathrm{Fe}^{2+}$, and subordinated significance have following compounds: $\mathrm{FeSO}_{4}$, $\mathrm{FeHCO}_{3}$ and $\mathrm{FeCO}_{3}$. Similar results are obtained for the Salaspils aquifer, where more than $63 \%$ of iron migrates as $\mathrm{Fe}^{2+}$. Nevertheless the part of complex compounds reaches $37 \%$, and essential increase of $\mathrm{FeCO}_{3}$ and $\mathrm{FeHCO}_{3}$ is observed. Reason is very clear - water mineralization is $0.3-0.6 \mathrm{~g} / \mathrm{l}$ and 2.2-2.6 g/l correspondingly in the Quaternary multi-aquifer and in the Salaspils aquifer.

Total iron content in aquifers is different, and varies from $8.4 \mathrm{mg} / 1$ to $36.0 \mathrm{mg} / 1$ in the Quaternary multiaquifer and from $1.58 \mathrm{mg} / 1$ to $5.2 \mathrm{mg} / \mathrm{l}$ in the Salaspils aquifer.

\section{Iron distribution in $\mathrm{O}_{2}$ and sulphides non- containing water rich with organic matter}

Different situation observed in case when water is rich with organic matter, especially with humic and fulvic acids. With them iron forms stabile complexes, and for that reason migration of it occurs also in oxygen containing waters due to stability of complex compounds.

In literature $[7,8$, others] it is mentioned that iron forms complexes also with low-molecular carbonic acids (C1-10 - acetic acid, oxalic acid, citric acid, vinic acid and others). This item was not analyzed during our investigations, because the main attention was paid to the boggy sediments aquifer and to other aquifers significantly influenced by the water from boggy sediments aquifer providing essential increase of content of organic matter. Also it has to be emphasized that water of the boggy sediments aquifer does not contain carbonic acids [11].

$\mathrm{pH}$ of water in boggy sediments aquifer varies from 5.0 to 6.5 , but $\mathrm{Eh}-$ from $+75 \mathrm{mV}$ to $+205 \mathrm{mV}$. Forming of complexes with fulvic, humic acids and other organic compounds significantly slow down oxidation of $\mathrm{Fe}^{2+}$, and in single cases completely prevent the oxidation process, even more - reduction of $\mathrm{Fe}^{3+}$ to $\mathrm{Fe}^{2+}$ takes place in presence of organic matter. Moreover - created complexes are not subjected to hydrolysis in the particular media.

Kinetic of hydrolysis of $\mathrm{Fe}^{3+}$ depends on $\mathrm{pH}$ and ratio of fulvic acids and $\mathrm{Fe}^{3+}$ concentration in water. Therefore maximal $\mathrm{Fe}^{3+}$ concentrations (to $47.5 \mathrm{mg} / \mathrm{l}$ ) are found in water of the boggy sediments aquifer very rich with fulvic and humic acids (third type of water). 
Table 1.

REVIEW OF IRON MIGRATION FORMS IN GROUNDWATER OF THE KEMERI - JAUNKEMERI OCCURENCE OF SULPHIDE CONTAINING WATER

\begin{tabular}{|c|c|c|c|c|c|c|c|c|c|c|c|c|c|c|c|}
\hline \multirow{3}{*}{ Parameter } & \multirow{3}{*}{$\begin{array}{l}\text { Measure- } \\
\text { ment unit }\end{array}$} & \multicolumn{14}{|c|}{ Well or spring, aquifer } \\
\hline & & $\mathrm{V}-4$ & III-4 & $\mathrm{V}-3 \mathrm{e}$ & $\mathrm{V}-3 \mathrm{c}$ & LG-5 & LG-2 & LG-3 & 751 & $P$ & XVIII-3/2 & XVIII-3/z & XVIII-3/d & 709 & 950 \\
\hline & & $\lg \mathrm{Q}_{3} \mathrm{bl}$ & $\lg \mathrm{Q}_{3} \mathrm{bl}$ & $D_{3} \operatorname{slp}(1)$ & $D_{3} \operatorname{slp}(1)$ & $D_{3} \operatorname{sip}(1)$ & $D_{3} \operatorname{slp}(1)$ & $D_{3} \operatorname{slp}(1)$ & $D_{3} \operatorname{slp}(1)$ & $D_{3} \operatorname{slp}(1)$ & $D_{3} \operatorname{slp}(1)$ & $D_{3} \operatorname{slp}(1)$ & $D_{3} \operatorname{sip}(1)$ & $D_{3} \operatorname{slp}(2)$ & $\begin{array}{l}\mathrm{D}_{3} \mathrm{slp} \\
(2)\end{array}$ \\
\hline \begin{tabular}{|l|}
$\mathrm{Fe}^{2+}$, \\
determined
\end{tabular} & $\mathrm{mg} / \mathrm{l}$ & 36,0 & 8,4 & 0,4 & 1,2 & 0,3 & 0,6 & 0,9 & 0,4 & 0,2 & 0,54 & 0,2 & 0,4 & 1,5 & 1,1 \\
\hline$\Sigma \mathrm{Fe}^{2+}$ & g-ions/1 & \begin{tabular}{|l|}
$5,157^{*}$ \\
$10^{-4}$
\end{tabular} & $\begin{array}{l}8,594^{*} \\
10^{-5}\end{array}$ & $\begin{array}{l}7,162^{*} \\
10^{-6}\end{array}$ & $\begin{array}{l}2,149^{*} \\
10^{-5}\end{array}$ & $\begin{array}{l}5,372^{*} \\
10^{-6}\end{array}$ & $\begin{array}{l}1,074^{*} \\
10^{-5}\end{array}$ & $\begin{array}{l}1,611^{*} \\
10^{-5}\end{array}$ & $\begin{array}{l}7,162^{*} \\
10^{-6}\end{array}$ & $\begin{array}{l}3,581^{*} \\
10^{-6}\end{array}$ & $\begin{array}{l}9,669^{*} \\
10^{-6}\end{array}$ & $\begin{array}{l}5,370^{*} \\
10^{-6}\end{array}$ & $\begin{array}{l}7,162^{*} \\
10^{-6}\end{array}$ & $\begin{array}{l}2,686^{*} \\
10^{-5}\end{array}$ & $\begin{array}{l}1,970^{*} \\
10^{-5}\end{array}$ \\
\hline Activity of $\mathrm{Fe}^{2+}$ & g-ions/1 & \begin{tabular}{|l|}
$4,301^{*}$ \\
$10^{-4}$
\end{tabular} & $\begin{array}{l}7,303^{*} \\
10^{-5}\end{array}$ & $\begin{array}{l}2,081^{*} \\
10^{-8}\end{array}$ & $\begin{array}{l}7,260^{*} \\
10^{-8}\end{array}$ & $\begin{array}{l}1,868^{*} \\
10^{-8}\end{array}$ & $\begin{array}{l}3,819^{*} \\
10^{-8}\end{array}$ & $\begin{array}{l}5,218^{*} \\
10^{-8}\end{array}$ & $\begin{array}{l}2,106^{*} \\
10^{-8}\end{array}$ & $\begin{array}{l}2,785^{*} \\
10^{-8}\end{array}$ & $\begin{array}{l}2,667 * \\
10^{-8}\end{array}$ & $\begin{array}{l}3,171^{*} \\
10^{-8}\end{array}$ & $\begin{array}{l}1,724^{*} \\
10^{-8}\end{array}$ & $\begin{array}{l}1,701^{*} \\
10^{-5}\end{array}$ & $\begin{array}{l}1,261^{*} \\
10^{-5}\end{array}$ \\
\hline \multicolumn{16}{|l|}{ Migration forms } \\
\hline $\mathrm{Fe}^{2+}$ & $\% \mathrm{no} \mathrm{Fe}^{2+}$ & 83,4 & 84,97 & 0,3 & 0,34 & 0,35 & 0,36 & 0,32 & 0,29 & 0,78 & 0,27 & 0,55 & 0,37 & 63,34 & 64,02 \\
\hline $\mathrm{Fe}(\mathrm{OH})^{+}$ & $\% \mathrm{noFe}^{2+}$ & 0,14 & 0,16 & $<0,01$ & $<0,01$ & $<0,01$ & $<0,01$ & $<0,01$ & $<0,01$ & $<0,01$ & $<0,01$ & $<0,01$ & $<0,01$ & 0,15 & 0,25 \\
\hline $\mathrm{FeSO}_{4}{ }^{0}$ & $\% \mathrm{no} \mathrm{Fe}^{2+}$ & 11,4 & 3,35 & 0,07 & 0,09 & 0,09 & 0,10 & 0,08 & 0,09 & 0,20 & 0,07 & 0,15 & 0,10 & 10,13 & 10,29 \\
\hline $\mathrm{Fe}\left(\mathrm{SO}_{4}\right)_{2}^{2-}$ & $\% \mathrm{no} \mathrm{Fe}^{2+}$ & 0,29 & 0,02 & $<0,01$ & $<0,01$ & $<0,01$ & 0,01 & $<0,01$ & 0,01 & 0,02 & $<0,01$ & 0,01 & $<0,01$ & 0,45 & 0,42 \\
\hline $\mathrm{FeHCO}_{3}^{+}$ & $\% \mathrm{no} \mathrm{Fe}^{2+}$ & 3,72 & 8,89 & 0,09 & 0,12 & 0,12 & 0,11 & 0,11 & 0,08 & 0,15 & 0,10 & 0,12 & 0,11 & 17,89 & 14,78 \\
\hline $\mathrm{Fe}\left(\mathrm{HCO}_{3}\right)_{2}{ }^{0}$ & $\% \mathrm{no} \mathrm{Fe}^{2+}$ & 0,02 & 0,11 & $<0,01$ & $<0,01$ & $<0,01$ & $<0,01$ & $<0,01$ & $<0,01$ & $<0,01$ & $<0,01$ & $<0,01$ & $<0,01$ & 0,69 & 0,46 \\
\hline $\mathrm{FeCO}_{3}{ }^{0}$ & $\% \mathrm{no} \mathrm{Fe}^{2+}$ & 0,99 & 2,45 & 0,04 & 0,05 & 0,05 & 0,05 & 0,04 & 0,03 & 0,04 & 0,03 & 0,06 & 0,03 & 7,19 & 9,52 \\
\hline $\mathrm{Fe}(\mathrm{CO} 3)_{2}{ }^{2-}$ & $\% \mathrm{no} \mathrm{Fe}^{2+}$ & $<0,01$ & $<0,01$ & $<0,01$ & $<0,01$ & $<0,01$ & $<0,01$ & $<0,01$ & $<0,01$ & $<0,01$ & $<0,01$ & $<0,01$ & $<0,01$ & 0,11 & 0,18 \\
\hline $\mathrm{FeHS}^{-}$ & $\% \mathrm{noFe}^{2+}$ & - & - & 56,10 & 57,81 & 58,29 & 58,70 & 57,15 & 56,42 & 71,06 & 54,41 & 66,40 & 59,57 & - & - \\
\hline $\mathrm{Fe}(\mathrm{HS})_{2}{ }^{0}$ & $\%$ no Fe ${ }^{2+}$ & - & - & 43,38 & 41,58 & 41,08 & 40,67 & 42,28 & 44,08 & 27,74 & 45,10 & 32,69 & 39,81 & - & - \\
\hline \multicolumn{16}{|l|}{ Calculations } \\
\hline $\mathrm{Fe}^{2+}, \max$ & $\mathrm{mg} / \mathrm{l}$ & 13,1 & 5,3 & 357,9 & 283,6 & 272,8 & 248,8 & 319,5 & 442,8 & 285,4 & 431,9 & 228,6 & 397,9 & 1,80 & 1,36 \\
\hline $\mathrm{Fe}^{2+}=\operatorname{det} / \mathrm{max}$ & - & 2,75 & 1,58 & $1 * 10^{-3}$ & $4 * 10^{-3}$ & $1 * 10^{-3}$ & $2 * 10^{-3}$ & $3 * 10^{-3}$ & $9 * 10^{-4}$ & $7 * 10^{-4}$ & $1 * 10^{-3}$ & $4 * 10^{-4}$ & $9 * 10^{-4}$ & 0,83 & 0,81 \\
\hline
\end{tabular}

Legend:

springs: LG- Luznu gravis; P - Parka

aquifers: $\operatorname{lgQ}_{3}$ bl -aquifer of limnoglacial sediments of the Baltic Ice Lake; $\mathrm{D}_{3} \operatorname{slp}(1)$ un $\mathrm{D}_{3} \operatorname{slp}(2)$ - Salaspils aquifer,

sulphide containing (1) and non-containing (2) water

$\mathrm{Fe}^{2+}$, max - maximal possible concentration of $\mathrm{Fe}^{2+}$ assuming that $\mathrm{Fe}^{2+}$ should be in equilibrium with $\mathrm{FeCO}_{3}$

$\mathrm{Fe}^{2+}=$ det/max - rate among the determined and maximal possible $\mathrm{Fe}^{2+}$ concentration calculated theoretically

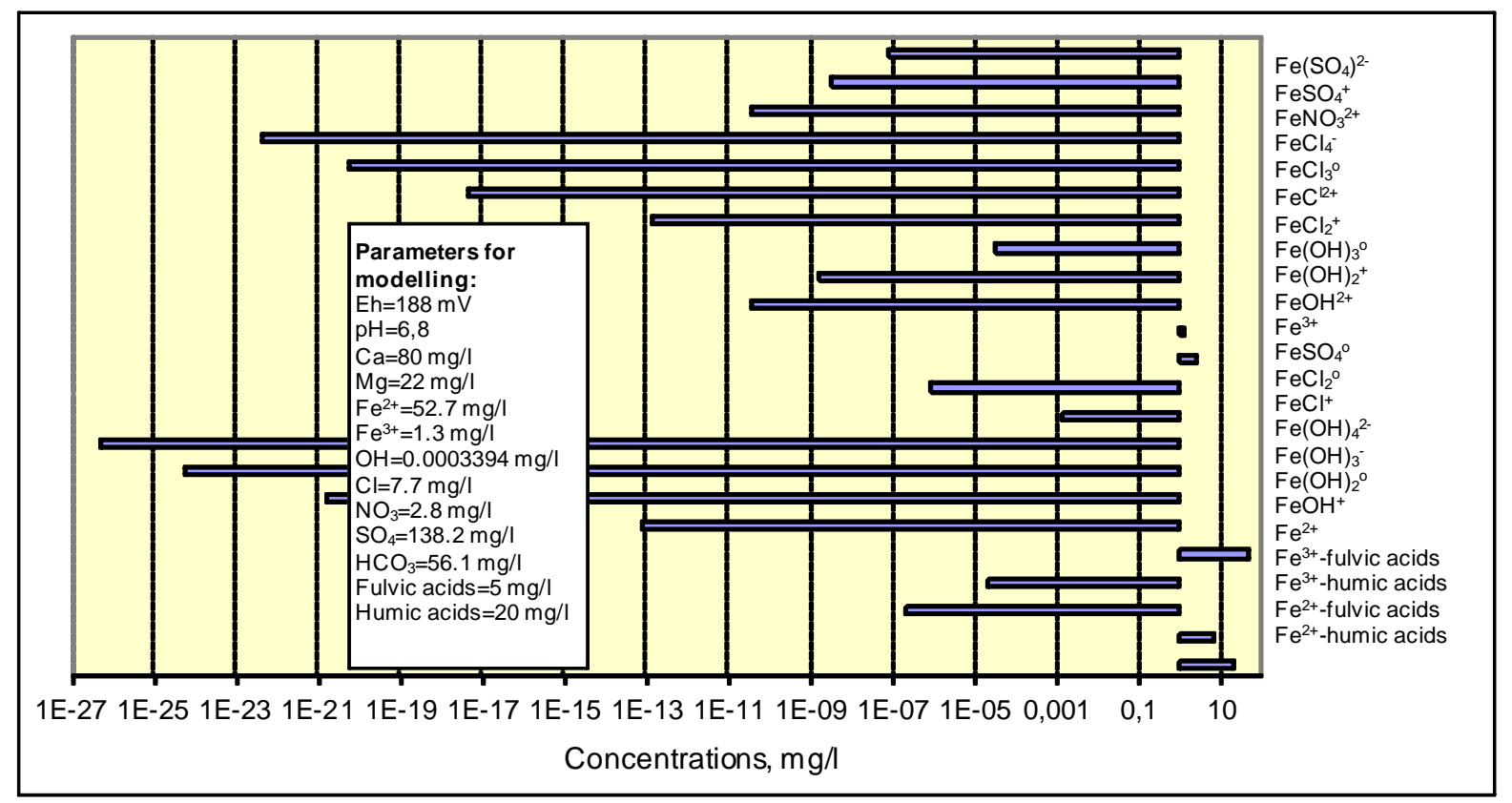

Fig. 4. Iron migration forms in the Baltic Ice Lake limnoglacial sediments aquifer

$\mathrm{OH}^{-}$ions activity essentially increases if alkalinity of water rises up, but is has to be emphasized that even in case of $\mathrm{pH}=7$ and fulvic acids - $\mathrm{Fe}^{3+}$ ratio $=10$, the rather high $\mathrm{Fe}^{3+}$ concentrations $(10-20$ $\mathrm{mg} / \mathrm{l})$ still remain in the third type of water. It has to be concluded that actual iron concentrations comparing with theoretically calculated ones are significantly higher due to creation of complexes among iron and humic and fulvic acids.

Forming of complexes among iron and organic matter has high hydrogeochemical importance, because:
- $\quad$ hydrolysis of the complex compounds of Fe3+ and fulvic and humic acids is very weak,

- $\quad$ standard oxred value for fulvic and humic acids is lower than for system $\mathrm{Fe} 3+/ \mathrm{Fe} 2+$, what determines reduction of $\mathrm{Fe} 3+$ in presence of those organic compounds,

- fulvic and humic acids in large extent prevent oxidation of $\mathrm{Fe} 2+$ in cases when conditions of aqua - media are changing [7].

Fig. 4 shows distribution of iron migration forms in the Quaternary multi-aquifer in case when concentrations of fulvic and humic acids are relatively 
low and water does not contain $\mathrm{O}_{2}$ and sulphides. These conditions are typical for the Baltic Ice Lake limnoglacial sediments aquifer, and the sampled well was located at the eastern part of the Lielais Tirelis bog, where aquifer, to a greater or lesser extent, is recharged by water from the boggy sediments aquifer.

In particular conditions $\mathrm{Fe}^{2+}$, according modelling results, migrates both in form of free ion and complex compounds. Furthermore - the sum of complex compounds is higher than value migration in a form of $\mathrm{Fe}^{2+}$, but $\mathrm{Fe}^{3+}$ basically migrates in a form of free ion. Rank of the main migration forms is following:

$\mathrm{Fe}^{2+}>\mathrm{Fe}^{2+}$-humic acids $>\mathrm{Fe}^{2+}$-fulvic acids $>$ $\mathrm{FeSO}_{4}>\mathrm{Fe}^{3+}$

Taking into account that $\mathrm{Fe}^{2+}$ is one the main oxred forming components in the Quaternary multi-aquifer, it has to be concluded that:

- $\mathrm{Fe}^{2+}$ forms complexes not only with fulvic and humic acids, but also with sulphates,

- abnormally high content of $\mathrm{Fe}^{2+}$ in the boggy water is determined by low $\mathrm{pH}$ causing great increase of migration ability of iron and simultaneous creation of complexes of it with fulvic and humic acids

Distribution of iron in sulphides containing water

Iron migration, according results of investigations, is ascertained also in sulphide containing water (IV type). This occurs due to creation of $\mathrm{Fe}^{2+}$ complexes basically with $\mathrm{HS}^{-}$:

$\mathrm{Fe}^{2+}+\mathrm{nHS}^{-} \leftrightarrow \mathrm{Fe}(\mathrm{HS})_{\mathrm{n}}^{2-\mathrm{n}}[4]$

Rise up of $\mathrm{pH}$ of water determines increase of alkalinity, and consequently increase of concentration of $\mathrm{S}^{2-}$ ions. In this case, simultaneously with reaction [4], the following process is ongoing:

$\left.\mathrm{Fe}^{2+}+\mathrm{S}^{2-} \leftrightarrow \mathrm{FeS}\right) \downarrow[5]$

Nevertheless the process [5] has only theoretical character in case of the Kemeri - Jaunkemeri occurrence, because $\mathrm{pH}$ value normally does not exceed 7.2-7.4.

In general iron concentrations in this type of water are low and very rarely exceed $1 \mathrm{mg} / \mathrm{l}$ (maximal concentration is $1.2 \mathrm{mg} / \mathrm{l})$. Simultaneously formation of pyrite $\left(\mathrm{FeS}_{2}\right)$ and mackinawite $(\mathrm{FeS})$ was observed in the Salaspils aquifer, where it is recharged by oxygen containing groundwater from the Quaternary multi-aquifer. Oxidation of $\mathrm{H}_{2} \mathrm{~S}^{0}$ and $\mathrm{HS}^{-}$causes not only decrease of their concentrations, but also destruction of $\mathrm{Fe}(\mathrm{HS})_{\mathrm{n}}{ }^{2-\mathrm{n}}$ complexes. Process causes increase of $\mathrm{pH}$ of water due to involvement of $\mathrm{H}^{+}$ion in reactions. This process is described by following equations:

$\mathrm{HS}^{-}+\mathrm{H}^{+}=\mathrm{H}_{2} \mathrm{~S} \uparrow[6]$

$2 \mathrm{HS}^{-}+2 \mathrm{H}^{+}+\mathrm{O}_{2}=2 \mathrm{SO}+2 \mathrm{H}_{2} \mathrm{O}[7]$

Concentrations of $\mathrm{S}^{-}$are increasing in water due to deviation of $\mathrm{pH}$ towards alkaline conditions. This, jointly with processes [6] and [7] determines deposition of pyrite and mackinawite. Processes are described by following equations:

$\left.\mathrm{Fe}^{2+}+\mathrm{S}^{2-}=\mathrm{FeS} \downarrow 8\right]$
$\mathrm{Fe}^{2+}+\mathrm{S}^{2-}+\mathrm{S}^{0}=\mathrm{FeS}_{2} \downarrow[9]$

Further oxidation of sulphides takes place releasing $\mathrm{H}+$ ion, what leads to decrease of alkalinity. Those processes are describing following equations:

$\mathrm{H}_{2} \mathrm{~S}+2 \mathrm{O}_{2}=\mathrm{SO}_{4}{ }^{2-}+2 \mathrm{H}^{+}[10]$

$\mathrm{HS}^{-}+2 \mathrm{O}_{2}=\mathrm{SO}_{4}^{2-}+\mathrm{H}^{+}[11]$

$2 \mathrm{SO}+2 \mathrm{O}_{2}+2 \mathrm{H}_{2} \mathrm{O}=2 \mathrm{SO}_{4}^{2-}+4 \mathrm{H}^{+}[12]$

Two iron migration forms - FeHS ${ }^{-}$and $\mathrm{Fe}(\mathrm{HS})_{2}{ }^{0}$ (see Table 1) are dominating in the Salaspils aquifer, where water contains sulphides. They present absolutely dominating part of migration forms $98.8 \%$. Distribution of other migration forms: $\mathrm{Fe}^{2+}$, $\mathrm{FeOH}^{+}, \mathrm{FeSO}_{4}{ }^{0}$ and $\mathrm{FeHCO}_{3}{ }^{+}$, is very limited $(0,1 * \%)$.

Finally it has to be mentioned that maximal actual concentration of iron $(1.2 \mathrm{mg} / \mathrm{l})$ in this water is very far from theoretically possible (see Table 1).

III RESULTS, CONCLUSION AND DISCUSSION

Use either SI (MKS) or CGS as primary units. (SI units are encouraged.) English units may be used as secondary units (in parentheses). An exception would be the use of English units as identifiers in trade, such as "3.5-inch disk drive".

If you must use mixed units, clearly state the units for each quantity that you use in an equation.

Study results of the Kemeri-Jaunkemeri occurrence of sulphide containing groundwater allow to provide following conclusions:

1) Mainly $\mathrm{Fe}^{2+}$ is distributed in groundwater of the occurrence, excluding particular locations where in aquifers have water containing $\mathrm{O}_{2}$. $\mathrm{Fe}(\mathrm{OH})_{3}$ absolutely dominates in this type of water.

2) Iron concentration, its migration forms and saturation of water with iron are extremely different not only for different aquifers, but also within the productive Salaspils aquifer as well. Therefore during mixing of various types of water, most frequently, degradation of occurrence takes place. Hereto the main role in those processes is playing oxygen, but presence of iron in water also has rather serious influence - form example, it determinates formation of pyrite and mackinawite. Especially a formation of mackinawite causes serious problems, because the most intensively this process is ongoing in zone of air -water contact in wells (water table fluctuations are 1.2-1.8 $\mathrm{m} / \mathrm{year}$ ), what causes the fast degradation of a well.

3) Results of investigations proved that iron forms complexes with organic matter, in particular case with fulvic and humic acids what leads to significant increase of total iron concentrations in groundwater rich with mentioned substances. Those organic acids can not be used by sulphate reduction bacteria, but still is opened question - does iron forms complexes with organic substances which may be consumed by mentioned bacteria? This is problem has to be investigated in future in order to understand rate of influence of this process to origin and distribution of sulphides in groundwater of the occurrence. 


\section{REFERENCES}

[1] Hem J.D.. Chemical Factors that influence the Availability of Iron and Manganese in Aqueous Systems. Geological Society of America Bulletin, v.83, no. 2. 1972, Geological Society of America. -p. 443-450.

[2] Hem J.D.. Chemical Equilibrium Diagrams for Ground-water Systems. Principles and Application of aquatic chemistry. New York, Wiley-IEEE PH, 1993. -p.45-53.

[3] Kennedy V., Zellweger G. Filter pore-size effects in the analysis of $\mathrm{Al}, \mathrm{Fe} ., \mathrm{Mn}$ and $\mathrm{Ti}$ in water. Water Resources Research, v.10., no. 4. 1974. - p.785.

[4] Singer, P.C., Stumm W. The solubility of ferrous iron in carbonate-bearing water. Journal of American Water Works Association, vol. 63, №3, 1970. -p. 198-202.

[5] Diliūnas J., Jurevičius A. Geležis Lietuvos gelame pažeminiame vandenyje. Vilnius, Lietuvos geologijos tarnyba, 1998, 76 p. /Diliunas J., Jurevicius A. Iron in drinking groundwater of Lithuania. Vilnius, Geological Survey of Lithuania, 1998, 76 p. In Lithuanian/.

[6] Государственный контроль качества минеральной воды и напитков. Научный руководитель - Е.Т.Зуев. Москва, Издательство стандартов, 2003, 840 c. State control of the quality of mineral water and drinks. Scientific supervisor E.T.Zuev. Moscow, Publishing house of standards, 2003, 840 p.

[7] Крайнов С.Р., Соломин Г.А., Василькова Г.И. и др. Геохимические типы железосодержащих подземных вод с околонейтральной реакцией. Геохимия, № 3, 1982, с. 400420. /Krainov S.R., Solomin G.A., Vasilkova G.A., et. al. Geochemical types of iron containing groundwater with nearly neutral reaction. Geochemistry, No. 3, 1982, p. 400-420. In Russian/.

[8] Крайнов С.Р., Соломин Г.А., Закутин В.П. Железо в подземных водах хозяйственно-питьевого назначения. Москва, серия «Гидрогеология и инженерная геология», ВИЭМС, 1987, 56 c. /Krainov S.R., Solomin G.A., Zakutin
V.P. Iron in groundwater for household - drinking needs. Moscow, series "Hydrogeology and Engineering Geology", VIEMS, 1987, 56 p. In Russian/.

[9] Крайнов С.Р., Швец В.М. Геохимия подземных вод хозяйственно - питьевого назначения. Moscow, Недра, 1987, 237 p. Krainov S.R., Shvetcz V.M. Geochemistry of groundwater applied for industrial - drinking needs. Moscow, Nedra, 1987, $237 \mathrm{p}$.

[10] Пролс Я.А. Формирование и распределение сероводорода в Кемерском месторорождении сульфидных вод. В книге: Минеральные воды Советской Прибалтики и перспективы их использования для курортного строительства. Вильнюс: Литовский научно-исследовательский геологоразведочный институт, 1987. - c. 55-57. Prols J. Origin and distribution of hydrogen sulphide in the Kemeri occurrence of sulphide containing groundwater. In: Mineral water of Soviet Baltic and prospects for their utilisation for resort needs. Vilnius, Lithuanian Scientific Research Institute for Geology, 1987, p. 55-57. In Russian/.

[11] Пролс Я.А. Химический состав и строение органической массы болот, приуроченных к району месторождения слабосульфидных вод Кемери. В книге: Актуальные вопросы исследований природных рессурсов, рехабилитации и лечения больных на курортах Латвийской ССР. Рига, «Авотс», 1988, с. 36-40. . /Prols J. Chemical composition and structure organic matter of bogs developed at area of the Kemeri - Jaunkemeri occurrence of sulphide containing groundwater. In: Actual questions of investigation of nature resources, rehabilitation and treatment of patients at resorts of Latvian SSR. Riga, "Avots", 1988, p. 36-40. In Russian/.

Соломин Г.А. Ионные равновесия железа в подземных водах. Гидрохимические материалы. т. 43, Ленинград, Гидрометеоиздат, 1967, , с. 88-93. / Solomin G.A. Ionic equilibrium of iron in groundwater. In: Hydrochemical materials. Vol. 43, Leningrad, Hidrometeoizdat, 1967, p. 88$93 /$ 